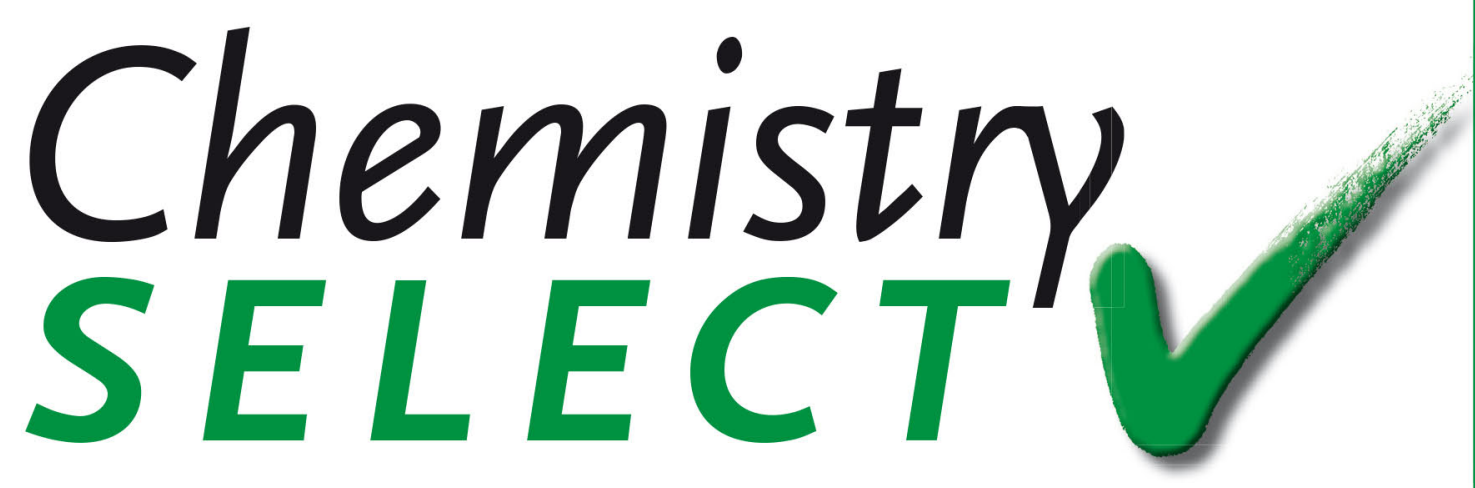

A journal of

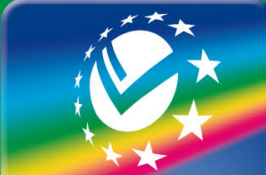

ChemPubSoc Europe

www.chemistryselect.org

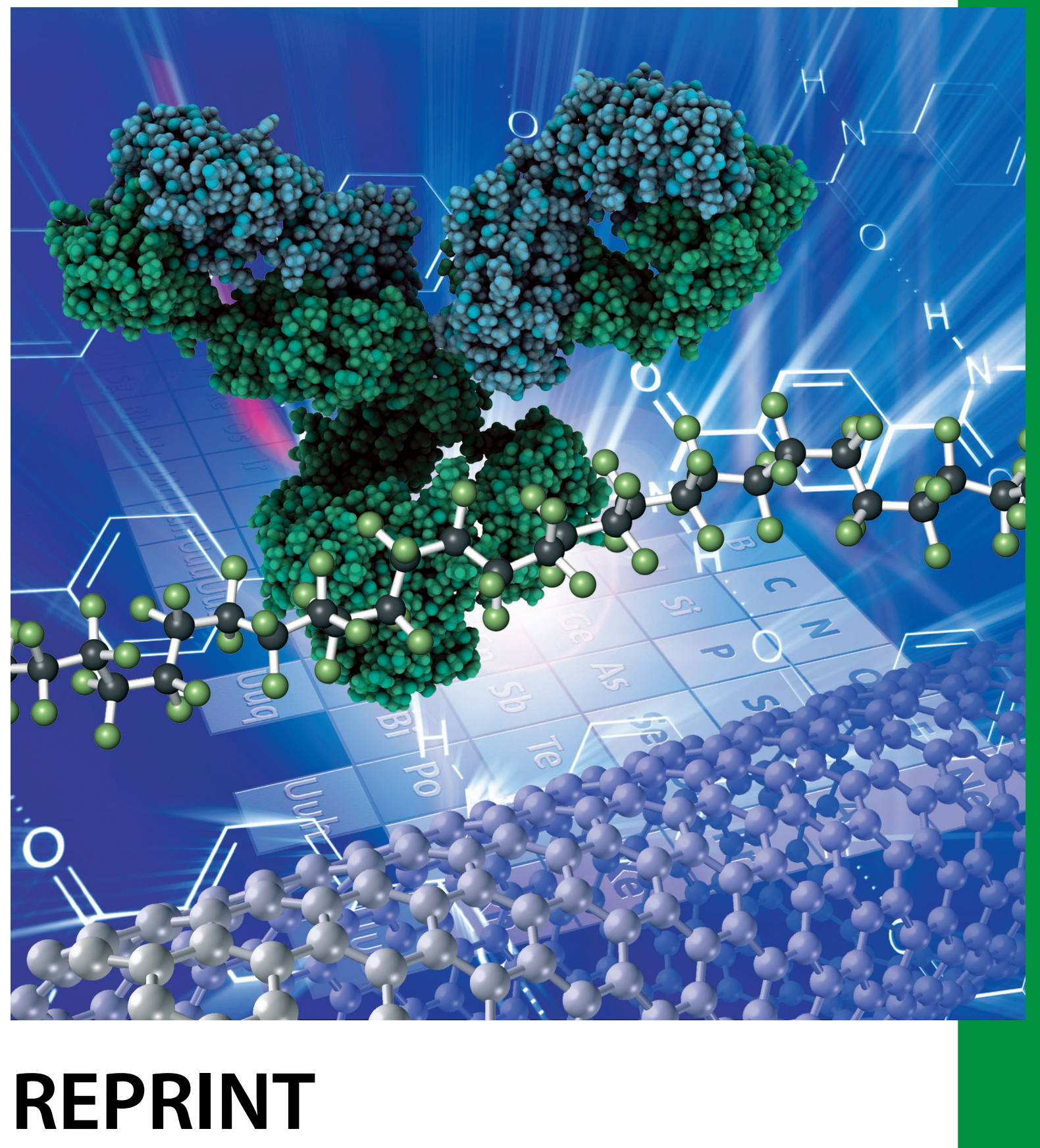

WILEY-VCH 


\title{
Role of Anion and Cation in the 1-Methyl-3-butyl Imidazolium Ionic Liquids BMImX: The Knoevenagel Condensation
}

\author{
Fabiana Pandolfi, Marta Feroci, and Isabella Chiarotto*[a]
}

This paper is dedicated to Prof. Achille Inesi, on the occasion of his 77th birthday.

1-Methyl-3-butylimidazolium ionic liquids $\mathrm{BMImX}(\mathrm{X}$ anions: $\left.\mathrm{Ac}^{-}, \mathrm{HCO}_{3}^{-}, \mathrm{Cl}^{-}, \mathrm{BF}_{4}^{-}, \mathrm{PF}_{6}^{-}, \mathrm{I}^{-}, \mathrm{CF}_{3} \mathrm{CO}_{2}^{-},\left(\mathrm{CF}_{3} \mathrm{SO}_{2}\right)_{2} \mathrm{~N}^{-}, \mathrm{CF}_{3} \mathrm{SO}_{3}^{-}\right)$ were used as catalysts in the Knoevenagel condensation reaction. The catalytic activity was compared with that of the inorganic salts $\mathrm{NaAc}, \mathrm{NaHCO}_{3}, \mathrm{NaCl}$. Whereas it is quite important to select suitable cation and anion depending on the purpose, the basicity of the anion $X^{-}$and the ability of the counter-ion $\mathrm{BMIm}^{+}$to avoid the ion pairing with anion $\mathrm{X}^{-}$was investigated. 1-Methyl-3-butyl imidazolium acetate [BMImAc] and 1-methyl-3-butyl imidazolium hydrogen carbonate
$\left[\mathrm{BMImHCO}_{3}\right]$ show the most significant catalytic power and their catalytic effect was studied on a wide range of aromatic, heteroaromatic or aliphatic aldehydes or ketones with active methylene compounds. The corresponding substituted alkenes were obtained in excellent yields (up to 98\%) in the absence of any solvent at room temperature within short times. The interesting feature of this study includes explanation on role of the cation $\mathrm{BMIm}^{+}$as proton donor (versus anions $\mathrm{Ac}^{-}$or $\mathrm{HCO}_{3}^{-}$), in ion pair formation (with anion $\mathrm{X}^{-}$) and activator of the aldehyde structure.

\section{Introduction}

Ionic liquids (ILs) could be regarded as a class of salts, resulting from the association of a large organic cation with a weakly coordinating inorganic anion, that melt around $100^{\circ} \mathrm{C}$ or below. ${ }^{[1]}$ Owing to their peculiar singular physico-chemical properties (melting point, chemical and thermal stability, negligible vapour pressure, conductivity, solvating power etc.) ILs are frequently utilized in different fields: green solvent in organic synthesis, chemistry, electrochemistry, biochemistry, chemical engineering, new materials etc ${ }^{[2]}$ Imidazolium based ionic liquids are probably the most popular class of ILs. They are marked by a complex and intriguing reactivity related, inter alia, to the scaffold of the cation and the nature of the anion. The acidity of the imidazolium cation $\mathrm{BMIm}^{+}(\mathrm{pKa}=22$ in $\left.\mathrm{DMSO}^{[3]}\right)$ and the possible basicity of its counter ion $\left(\mathrm{Ac}^{-}, \mathrm{pKa}=\right.$ 4.76 in $\mathrm{H}_{2} \mathrm{O}, 12.6$ in DMSO; ${ }^{[4]} \mathrm{HCO}_{3}{ }^{-}$, pKa $=6.36$ in $\mathrm{H}_{2} \mathrm{O}, 10.25$ in $\mathrm{DMSO}^{[4]}$ ) are reported by many authors. The mutual interactions between $\mathrm{BMIM}^{+}$and $\mathrm{X}^{-}$were recently analysed. ${ }^{[5]}$ The formation of a new $\mathrm{C}-\mathrm{C}$ bond could be a serious hindrance (and an intriguing challenge) in a procedure of organic synthesis. The Knovenagel condensation between activated methylene compounds and aldehydes is a versatile reaction for

[a] Dr. F. Pandolfi, Prof. M. Feroci, Prof. I. Chiarotto

Department Dipartimento di Scienze di Base e Applicate per I'Ingegneria, Sapienza Università di Roma, Via del Castro Laurenziano 7-00161 Roma (Italy)

E-mail: Isabella.chiarotto@uniroma1.it

Supporting information for this article is available on the WWW under https://doi.org/10.1002/slct.201800295

the formation of $\mathrm{C}-\mathrm{C}$ bond through losing a molecule of water. In the classical procedure the condensation is performed in organic solvent in the presence of bases (Scheme 1). ${ }^{[6]}$<smiles>[R]C(=O)CC(C)(C)C</smiles>

Scheme 1. Classical procedure of condensation in organic solvent

Owing to its very frequent utilization in organic synthesis, the Knoevenagel reaction has spurred a continuous investigation aimed to find new, more efficient and green catalysts. Accordingly, the Knoevenagel reaction can be performed using bases, $^{[7]}$ Lewis acids, ${ }^{[8]}$ amino acids, ${ }^{[9]}$ organometallic compounds, ${ }^{[10]}$ enzymes, ${ }^{[11]} \mathrm{InCl}_{3}$ in the presence of acetic anhydride etc. ${ }^{[12]}$ The procedures can be carried out in the presence of water or organic solvents or in the absence of any solvent. Homogeneous and heterogeneous catalysts were reported. Many authors emphasize that the Knoevenagel reaction could be effectively catalysed by suitable ionic liquids. ${ }^{[13]}$

Thus it is interesting:

- to verify the possible utilization of 1-methyl-3-butylimidazolium ionic liquids $\mathrm{BMImX}$ (anion $\mathrm{X}=\mathrm{Ac}^{-}, \mathrm{HCO}_{3}^{-}, \mathrm{Cl}^{-}, \mathrm{BF}_{4}^{-}$, $\left.\mathrm{PF}_{6}{ }^{-}, \mathrm{I}^{-}, \mathrm{CF}_{3} \mathrm{CO}_{2}{ }^{-},\left(\mathrm{CF}_{3} \mathrm{SO}_{2}\right)_{2} \mathrm{~N}^{-}, \mathrm{CF}_{3} \mathrm{SO}_{3}^{-}\right)$, particularly the effect of 
<smiles></smiles>

\begin{tabular}{|c|c|c|}
\hline Catalyst & $x$ & $\mathbf{R}$ \\
\hline BMImAc & $\mathrm{CH}_{3} \mathrm{CO}_{2}$ & $\mathrm{H}$ \\
\hline $\mathrm{BMImHCO}_{3}$ & $\mathrm{HCO}_{3}$ & $\mathrm{H}$ \\
\hline BMImCl & $\mathrm{Cl}$ & $\mathrm{H}$ \\
\hline $\mathrm{BMImBF}_{4}$ & $\mathrm{BF}_{4}$ & $\mathrm{H}$ \\
\hline BMIml & I & $\mathrm{H}$ \\
\hline BMImTFA & $\mathrm{CF}_{3} \mathrm{CO}_{2}$ & $\mathrm{H}$ \\
\hline $\mathrm{BMImTf}_{2} \mathrm{~N}$ & $\left(\mathrm{CF}_{3} \mathrm{SO}_{2}\right)_{2} \mathrm{~N}$ & $\mathrm{H}$ \\
\hline BMImTfO & $\mathrm{CF}_{3} \mathrm{SO}_{3}$ & $\mathrm{H}$ \\
\hline $\mathrm{BMImPF}_{6}$ & $\mathrm{PF}_{6}$ & $\mathrm{H}$ \\
\hline BDMImAc & $\mathrm{CH}_{3} \mathrm{CO}_{2}$ & $\mathrm{CH}_{3}$ \\
\hline
\end{tabular}

$\mathrm{NaX}$

\begin{tabular}{ll} 
Catalyst & $\mathbf{X}$ \\
\hline $\mathrm{NaAc}$ & $\mathrm{CH}_{3} \mathrm{CO}_{2}$ \\
$\mathrm{NaHCO}$ & $\mathrm{HCO}_{3}$ \\
$\mathrm{NaCl}$ & $\mathrm{Cl}$ \\
\hline
\end{tabular}

Figure 1. 1-Methyl-3-butylimidazolium ionic liquids BMImX and inorganic salts $\mathrm{NaX}$ used as catalysts in the Knovenagel reaction.

$\mathrm{BMImHCO}_{3}$ currently not yet considered by other authors, compared to inorganic salts $\mathrm{NaX}$ as catalysts in the Knovenagel reaction (Figure 1).

- to evaluate the peculiar role played by the anion $\mathrm{X}^{-}$and the one of the cations $\mathrm{BMIm}^{+}$and $\mathrm{Na}^{+}$.

\section{Results and Discussion}

The use of ionic liquids BMImX and other inorganic salts in the Knoevenagel condensation results very interesting to compare the behaviour and the role of the anion and cation. We initially verified the possible catalytic activity of ionic liquids $\mathrm{BMImX}$ (Figure 1) with $\mathrm{C}-\mathrm{H}$ acid $\mathrm{CN}\left(\mathrm{CH}_{2}\right) \mathrm{CO}_{2} \mathrm{Et} 2 \mathrm{a}$ and benzaldehyde $\mathrm{PhCHO} 1 \mathrm{a}$ chosen as substrate samples. The effect of the presence in the reaction mixture of the imidazolium ionic liquids BMImX was then compared with the one of the inorganic salts $\mathrm{NaAc}, \mathrm{NaHCO}_{3}$ and $\mathrm{NaCl}$ (Figure 1). The presence and the nature of the solvent, the molar ratio substrates/ catalyst (i.e. the catalytic or stoichiometric quantity of ionic liquid) and the value of the temperature could affect the efficiency of the reaction. Accordingly, to have comparable results, any evaluation of the efficiency of the catalyst was carried out at room temperature, in the absence of any solvent and using catalytic quantity of ionic liquid (\% $\leq 10)$.

A mixture of PhCHO 1 a $(1.0 \mathrm{mmol})$ and $\mathrm{CN}\left(\mathrm{CH}_{2}\right) \mathrm{CO}_{2}$ Et $2 \mathrm{a}$ $(1.0 \mathrm{mmol})$, and catalyst (added at a prefixed concentration, see Table 1) was stirred at room temperature. The stirring was stopped after different prefixed values of the reaction time.

We can note that:

i) In the absence of catalyst (stirring time $24 \mathrm{~h}, \mathrm{rt}$ ), the analysis of the final mixture shows the total absence of the Knovenagel adduct 3aa (Table 1, entry 1).

ii) In the presence of BMImAc, the efficiency of the procedure is affected by the concentration of BMImAc and by the stirring time. Selecting a stirring time of $24 \mathrm{~h}$, the yield of the Knoevenagel adduct 3 aa increases on increasing the concentration of BMImAc (Table 1, entries 2-6).

\begin{tabular}{|c|c|c|c|c|}
\hline \multirow[b]{2}{*}{ Entry } & \multirow{2}{*}{$\begin{array}{l}\mathrm{PhCHO} \\
\text { 1a } \\
\text { Catalyst }\end{array}$} & \multirow{2}{*}{$\begin{array}{l}\mathrm{CN}_{2} \\
\mathrm{CO}_{2} \mathrm{Et} \\
\text { Catalyst (\%) }\end{array}$} & \multirow{2}{*}{\multicolumn{2}{|c|}{$\underset{\text { Rolvent, } \mathrm{rT}}{\text { Catalyst }}$}} \\
\hline & & & & \\
\hline 1 & - & - & 24 & - \\
\hline 2 & BMImAc & 3 & 24 & 39 \\
\hline 3 & BMImAc & 4 & 24 & 55 \\
\hline 4 & BMImAc & 5 & 24 & 63 \\
\hline 5 & BMImAc & 7 & 24 & 80 \\
\hline 6 & BMImAc & 10 & 24 & 98 \\
\hline 7 & BMImAc & 10 & 1.5 & 95 \\
\hline 8 & BMImAc & 10 & 0.5 & 93 \\
\hline 9 & $\mathrm{BMImHCO}_{3}$ & 10 & 1.0 & 90 \\
\hline 10 & $\mathrm{BMImHCO}_{3}$ & 10 & 24 & 95 \\
\hline 11 & $\mathrm{BMImCl}$ & 10 & 24 & 15 \\
\hline 12 & $\mathrm{BMImBF}_{4}$ & 10 & 24 & - \\
\hline 13 & $\mathrm{BMImPF}_{6}$ & 10 & 24 & - \\
\hline 14 & BMIml & 10 & 24 & 20 \\
\hline 15 & BMImTFA & 10 & 24 & 50 \\
\hline 16 & $\mathrm{BMImTf}_{2} \mathrm{~N}$ & 10 & 24 & - \\
\hline 17 & BMImTfO & 10 & 24 & - \\
\hline 14 & $\mathrm{NaAc}$ & 10 & 24 & 25 \\
\hline 15 & $\mathrm{NaAc}$ & 10 & 1.5 & - \\
\hline 16 & $\mathrm{NaHCO}_{3}$ & 10 & 24 & 50 \\
\hline 17 & $\mathrm{NaHCO}_{3}$ & 10 & 1.5 & - \\
\hline 18 & $\mathrm{NaCl}$ & 10 & 24 & 3 \\
\hline 19 & $\mathrm{NaCl}$ & 10 & 1.5 & - \\
\hline 20 & BDMImAc & 10 & 0.5 & 98 \\
\hline 21 & BDMImAc & 10 & 1.5 & 98 \\
\hline
\end{tabular}

[a] A mixture of PhCHO $1 \mathrm{a}(1.0 \mathrm{mmol})$ and $\mathrm{CN}\left(\mathrm{CH}_{2}\right) \mathrm{CO}_{2} \mathrm{Et} 2 \mathrm{a}(1.0 \mathrm{mmol})$, and catalyst was stirred at room temperature. [b] Isolated yield.

iii) Selecting a concentration of BMImAc of $10 \%$, the yield of 3aa increases on increasing of the stirring time (Table 1, entries 6-8).

iv) The catalytic ability of $\mathrm{BMImHCO}_{3}$ is comparable with the one of BMImAc (Table 1, entries 9, 10).

v) On the contrary, using the imidazolium ionic liquid $\mathrm{BMImCl}$ or BMIml, the yield of the Knoevenagel adduct 3aa decreases significantly (Table 1, entries 11 and 14), while the lower basicity of trifluoroacetate anion (in comparison to acetate anion) leads to lower yields (Table 1, entry 6 vs 15). No adduct 3aa was obtained using ionic liquids $\mathrm{BMImBF}_{4}$ and $\mathrm{BMImPF}_{6}$ as well as $\mathrm{BMImTf}_{2} \mathrm{~N}$ and BMImTfO (Table 1, entries $12,13,16,17)$.

Finally, we investigated the possible utilization as catalyst of inorganic salts $\mathrm{NaAc}, \mathrm{NaHCO}_{3}$ and $\mathrm{NaCl}$ to compare the ion pairing ability of cation $\mathrm{Na}^{+}$, versus $\mathrm{BMIm}^{+}$, over the anions. In all cases, established a stirring time of $1.5 \mathrm{~h}$, no adduct 3aa was obtained (Table 1, entries 15, 17, 19). Instead, selecting a stirring time of $24 \mathrm{~h}$, the adduct 3aa was obtained according to the yields $25 \%(\mathrm{NaAc}), 50 \%\left(\mathrm{NaHCO}_{3}\right)$ and $3 \%(\mathrm{NaCl})$ (Table 1, entries 14, 16, 18).

The considerable catalytic activity of BMImAc and BMImH$\mathrm{CO}_{3}$, compared with that of $\mathrm{BMImCl}, \mathrm{BMImBF}_{4}$ and $\mathrm{BMImPF}_{6}$, suggests that in the imidazolium based ionic liquids the role of 
the anion is very important. The catalytic activity of BMImAc and $\mathrm{BMImHCO}_{3}$ must be related chiefly to the anion basicity. Concerning this, we should keep in mind that the basicity of the anions $\mathrm{Ac}^{-}$and $\mathrm{HCO}_{3}{ }^{-}$is not negligible $(\mathrm{pKa}=12.6$ and 10.25 respectively in DMSO. These values are only indicative, as our reaction is carried out under solventless conditions). ${ }^{[4]}$ The efficiency of a catalytic process is evaluable, ceteris paribus, both by the final yield of the isolated product and by the reaction times. In our reaction conditions, the limited catalytic activity of $\mathrm{NaAc}$ and $\mathrm{NaHCO}_{3}$ (low yields and long reaction times), with respect to $B M I m A C$ and $B M I m \mathrm{HCO}_{3}$, suggests that the ion pairing ability of the cation $\mathrm{Na}^{+}$is remarkable with respect to the one of the large organic cation with low charge density $\mathrm{BMIm}^{+}$. The base catalysed Knoevenagel reaction is triggered by the deprotonation of the $\mathrm{C}-\mathrm{H}$ acid yielding the related carbanion, followed by the attack of the carbanion to the scaffold of benzaldehyde.

The catalytic activity of BMImAc or $\mathrm{BMImHCO}_{3}$, in the Knoevenagel condensation suggests the presence of a proton exchange equilibrium between anions $\mathrm{Ac}^{-}$or $\mathrm{HCO}_{3}^{-}$and $\mathrm{CN}\left(\mathrm{CH}_{2}\right) \mathrm{Y}$ (Scheme 2, eq. 1). The anion $\mathrm{Ac}^{-}$(as well as $\mathrm{HCO}_{3}{ }^{-}$) is

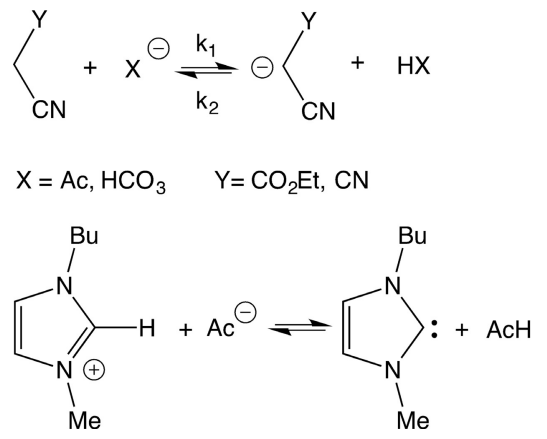

Scheme 2. A proton exchange equilibrium between anions and $\mathrm{CN}\left(\mathrm{CH}_{2}\right) \mathrm{Y}$ (eq. 1) and cation BMIm (eq. 2).

basic enough to establish a significant equilibrium of proton exchange with the $\mathrm{C}-\mathrm{H}$ acids $\mathrm{CNCH}_{2} \mathrm{Y} \mathbf{2} \mathbf{a}$ and $\mathbf{2} \mathbf{b}$. $^{[4]}$ The anions $\mathrm{Ac}^{-}$(pKa $=12.6$ in $\left.\mathrm{DMSO}\right)$ and $\mathrm{HCO}_{3}^{-}$(pKa $=10.25$ in $\left.\mathrm{DMSO}\right)$ are thus able to promote an operative endogenous proton exchange equilibrium with $\mathrm{C}-\mathrm{H}$ acids $\mathrm{CN}\left(\mathrm{CH}_{2}\right) \mathrm{CO}_{2} \mathrm{Et}$ ( $\mathrm{pKa}=13.1$ in DMSO) and $\mathrm{CH}_{2}(\mathrm{CN})_{2}$ (pKa=16.4 in DMSO), yielding the related carbanions $\mathrm{CN}\left(\mathrm{CH}^{-}\right) \mathrm{CO}_{2} \mathrm{Et}$ and $\mathrm{CH}^{-}(\mathrm{CN})_{2}$. These active methylene compounds start the catalytic cycle via a nucleophilic addition to the carbonyl group of the aldehyde or ketone scaffold. Accordingly, the endogenous equilibrium of proton exchange could be regarded as a source of the carbanions $\mathrm{CN}\left(\mathrm{CH}^{-}\right) \mathrm{CO}_{2} \mathrm{Et}$ and $\mathrm{CH}^{-}(\mathrm{CN})_{2}$ able to provide the catalytic cycle.

The efficiency of the $\mathrm{Ac}^{-}$anion as catalyst in the Knoevenagel reaction is affected by the thermodynamics of the equilibrium (1) (affected by the values of the pKa of $\mathrm{Ac}^{-}$and $\left.\mathrm{CN}\left(\mathrm{CH}_{2}\right) \mathrm{CO}_{2} \mathrm{Et}\right)$ as well as by the related kinetic values of $\mathrm{k}_{1}$ and $\mathrm{k}_{2}$ (Scheme 2). ${ }^{[4]}$ The different ion pairing ability (versus the counter-ion $\mathrm{Ac}^{-}$) of cations $\mathrm{Na}^{+}$and $\mathrm{BMIm}^{+}$could significantly modify the kinetics of the equilibrium of the proton exchange, affecting the reaction times. The cation $\mathrm{BMIm}^{+}$shows a lower ion pairing ability than $\mathrm{Na}^{+}$versus the anion $\mathrm{X}^{-}$, rendering it more reactive. Moreover, it cannot be excluded a role of the $\mathrm{BMIm}^{+}$cation as hydrogen bond doror activating the carbonyl moiety. ${ }^{[13 c]}$ The utilization as catalysts of $\mathrm{BMImAc}$ or $\mathrm{BMImHCO}_{3}$ ensures the best results as regard the yield and the reaction time. Both this salts are marked by anion and cation able to carry out the catalytic process.

On the contrary, the utilization as catalyst of $\mathrm{NaAc}, \mathrm{NaHCO}_{3}$, $\mathrm{BMImCl}$ or $\mathrm{NaCl}$ involves a significant decrease of the yields and longer reaction times.

The investigation of the Knoevenagel condensation catalysed by the ionic liquid $\mathrm{BMImHCO}_{3}$ and involving the $\mathrm{C}-\mathrm{H}$ acids $\mathrm{CN}\left(\mathrm{CH}_{2}\right) \mathrm{CO}_{2} \mathrm{Et} 2 \mathbf{a}$ and $\mathrm{CH}_{2}(\mathrm{CN})_{2} \mathbf{2} \mathbf{b}$ was extended to different aromatic (Table 2, entries 1-7, 12-17), heteroaromatic (Table 2, entries 10,11,19), aliphatic (Table 2, entries 8, 18) aldehydes and ketones (Table 2 , entry 9). The corresponding substituted alkenes were obtained, in any case, in elevated yields ( $>90 \%$ ), in short stirring times, in the absence of any solvent using an equimolar mixture of $\mathrm{C}-\mathrm{H}$ acid and aldehydic or ketonic substrate at room temperature.

Last, we must keep in mind that the anion $\mathrm{Ac}^{-}$(as well as $\mathrm{HCO}_{3}{ }^{-}$) could be involved, in theory, in an equilibrium of proton exchange with the cation $\mathrm{BMIm}^{+}$beyond that with the $\mathrm{C}-\mathrm{H}$ acid present (i.e. $\mathrm{CN}\left(\mathrm{CH}_{2}\right) \mathrm{CO}_{2}$ Et or $\mathrm{CH}_{2}(\mathrm{CN})_{2}$ ) (Scheme 2, eq. 1 and 2 , respectively).

Nevertheless, the exogenous proton exchange equilibrium (1) is the only equilibrium of proton exchange operative involving $\mathrm{Ac}^{-}$at $\mathrm{T}<60^{\circ} \mathrm{C}$ (Scheme 2, eq. 1)..$^{[5]}$

In fact, the effectiveness of an equilibrium of the endogenous proton exchange between $\mathrm{BMIm}^{+}$and $\mathrm{Ac}^{-}$, in pure BMImAC or in organic solvent at $\mathrm{T}<60^{\circ} \mathrm{C}$, was definitively ruled out by us via electrochemical analysis that revealed that this equilibrium is operative at $\mathrm{T}>60^{\circ} \mathrm{C} .^{[13]}$

As a consequence, in the Knovenagel mixture selected by us, the cation $\mathrm{BMIm}^{+}$behaves as a better counter ion of reactive anions $\mathrm{Ac}^{-}$and $\mathrm{HCO}_{3}{ }^{-}$as it shows a lower ion pairing ability than $\mathrm{Na}^{+}$and possibly enhances the reaction rate due to its hydrogen bond donor ability. As regards this last question, we compared the catalytic activity of the ionic liquid BMImAc with the one of BDMImAc (i.e. an imidazolium cation with a methyl group in the C2-position, thus having a noteworthy minor hydrogen bond donor ability). We verified that although the catalytic activity of BMImAc and BDMImAc are comparable (Table 1, entry 21 vs. 7), the lack of an acidic hydrogen atom in $\mathrm{C}-2$ position renders BDMImAC a more efficient catalyst in shorter times (Table 1, entry 20 vs 8 ). ${ }^{[14]}$

\section{Conclusions}

A comparison between the behaviour of ionic liquids $\mathrm{BMImX}(\mathrm{X}$ $\left.=\mathrm{Ac}^{-}, \mathrm{HCO}_{3}^{-}, \mathrm{Cl}^{-}, \mathrm{BF}_{4}^{-}, \mathrm{PF}_{6}{ }^{-}, \mathrm{I}^{-}, \mathrm{CF}_{3} \mathrm{CO}_{2}^{-},\left(\mathrm{CF}_{3} \mathrm{SO}_{2}\right)_{2} \mathrm{~N}^{-}, \mathrm{CF}_{3} \mathrm{SO}_{3}{ }^{-}\right)$ as catalysts in the Knoevenagel reaction with the one of inorganic salts $\left(\mathrm{NaAc}, \mathrm{NaHCO}_{3}, \mathrm{NaCl}\right)$, allows to clarify the role of the anion $\mathrm{X}^{-}$and of the imidazolium cation $\mathrm{BMIm}^{+}(\mathrm{pKa}=22$ in DMSO) in this important base catalysed organic reaction. The utilization of the ionic liquid $\mathrm{BMImAc}$ and $\mathrm{BMImHCO}_{3}$ (concen- 


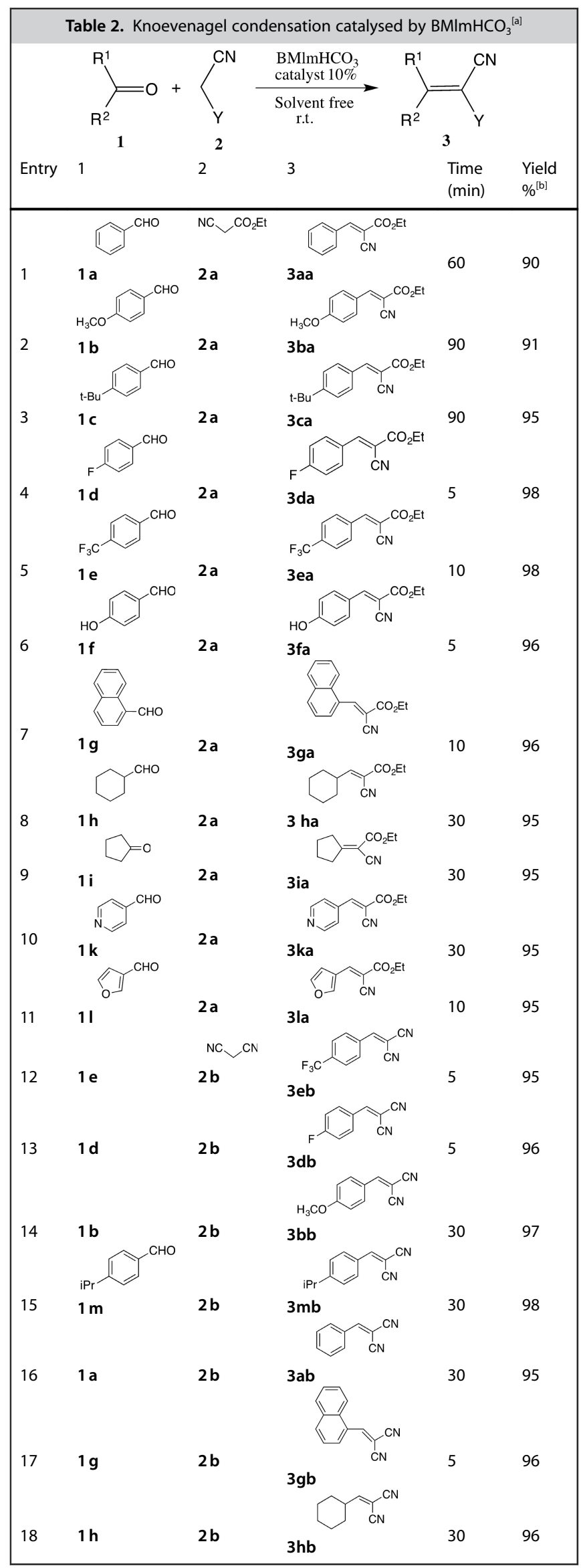

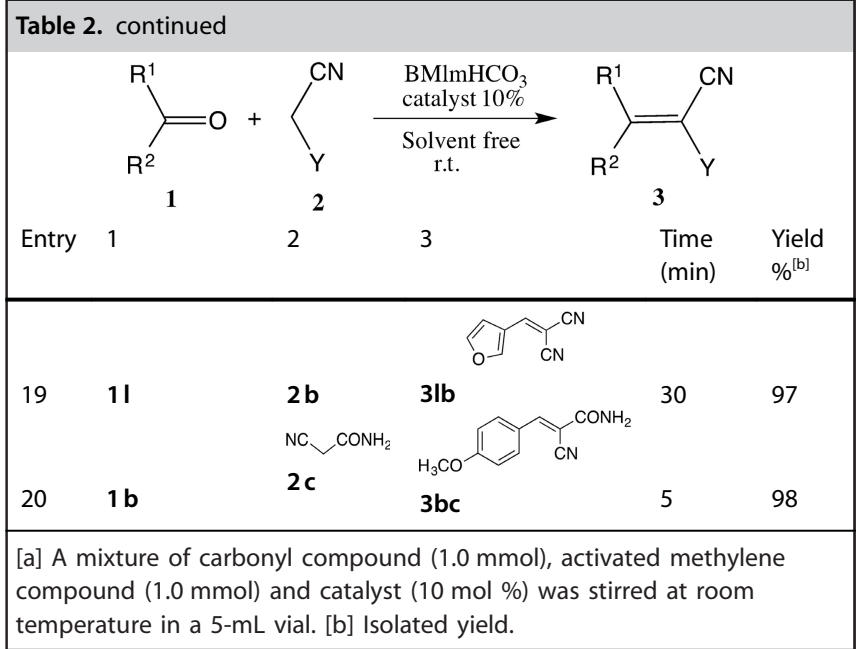

tration $\leq 10 \%$ ) in different Knoevenagel mixtures (aromatic, heteroaromatic, or aliphatic aldehydes or ketones with different active methylene compounds) allows to obtain the condensation products in very elevated yields (>95\%) and in short reaction times at room temperature in the absence of any solvent. The catalytic power of the ionic liquids is affected by the basicity of $\mathrm{X}^{-}$and by the ability of the large counter ion $\mathrm{BMIm}^{+}$to avoid the formation of ion pair. Accordingly, the catalytic power of BMImAc and $\mathrm{BMImHCO}_{3}$ is considerable; on the contrary, the one of $\mathrm{NaX}$ is minor or quite trifling.

The exogenous equilibrium of proton exchange between the anions $\mathrm{Ac}^{-}$and $\mathrm{HCO}_{3}{ }^{-}$and the cation $\mathrm{BMIm}^{+}$is not competitive with the endogenous proton exchange. Nevertheless, the formation of a hydrogen bond between $\mathrm{BMIm}^{+}$ and aldehyde cannot be ruled out.

\section{Supporting information summary}

Experimental procedure and all spectroscopic data are provided in the Supporting Information.

\section{Acknowledgements}

This work was supported by Miur (Italy) and Sapienza University of Rome.

\section{Conflict of Interest}

The authors declare no conflict of interest.

Keywords: BMIm Hydrogen Carbonate - Catalyst • Ionic liquids · Knoevenagel condensation · Solvent free

[1] P. Walden, Bull Acad. Sci. St. Petersburg 1914, 405-422.

[2] a) P. Wasserscheid, T. Welton in lonic Liquids in Synthesis, 2nd ed., WileyVCH, Weinheim, 2008; b) S. Sowmiah, C. I. Cheng, Y.-H. Chu, Curr. Org. Synth. 2012, 9, 74-95; c) J. P. Hallett, T. Welton, Chem. Rev. 2011, 111, 3508-3576; d) C. Chiappe in lonic Liquids in Synthesis, 2nd ed. (Eds.: P.Wasserscheid, T. Welton), Wiley-VCH, Weinheim, 2008, pp. 265-292; e) V. I. Pavulescu, C. Hardacre, Chem. Rev. 2007, 107, 2615-2665; f) M. 
Feroci, I. Chiarotto, A. Inesi, Curr. Org. Chem. 2013, 17, 204-219; g) C. Chiappe, A. Mezzetta, C. S. Pomelli, M. Puccini, M. Seggiani, Org. Process Res. Dev. 2016, 20, 2080-2084. h) A. Sarkar, S. R. Roy, A. K. Chakraborti, Chem. Comm. 2011, 47, 4538-4540. i) R. Kumar, Saima, A. Shard, N. H. Andhare, Richa, A. K. Sinha, Angew. Chem. 2015, 127, 842-846; Angew. Chem. Int. Ed. 2015, 54, 828-832. j) X. Zhang, G.-p. Lu, C. Cai, Green Chem. 2016, 18, 5580-5585. k) X. Zhang, G.-p. Lu, Z.-b. Xu, C. Cai, ACS Sustainable Chem. Eng. 2017, 5, 9279-9285.

[3] Y. Chu, H. Deng, J.-P. Cheng, J. Org. Chem. 2007, 72, 7790-7793.

[4] a) F. G. Bordwell, Equilibrium Acidities in Dimethyl Sulfixide Solution, Acc. Chem. Res. 1988, 21, p. 456; b) F. G. Bordwell, H. E. Fried, J. Org. Chem. 1981, 46(22), 4327-4331; c) F. G. Bordwell, J. C. Branca, D. I. Hughens, W. N. Olmstead, J. Org. Chem. 1980, 45, 3305-3315.

[5] Chiarotto, M. Feroci, A. Inesi, New J. Chem. 2017,41, 7840-7843.

[6] a) E. Knoevenagel, Ber. De. Chem. Ges. 1898, 31, 2596-2619; b) L. F. Tiezte, Chem. Rev. 1996, 96, 115-136; c) B. List, Angew. Chem. 2010, 122, 177-1779; Angew. Chem. Int. Ed. 2010, 49, 1730-1734. d) G. Jones in The Knoevenagel Condensation in Organic Reactions John Wiley, New York, 2011, 15, 204-599.

[7] a) Y.-X. Wang, L.-J. Wang, C.-P. Liu, R.-H. Wang, ChemCatChem 2015, 7, 1559-1565; b) S. Fujita, A. Katagiri, H. Watanabe, S. Asano, H. Yoshida, M. Arai, ChemCatChem 2015, 7, 2965-2970.

[8] a) V. Srinivas, M. Koketsu, J. Org. Chem. 2013, 78,11612-11617; b) J. S. Yadav, D. C. Bhunia, V. K. Sing, S. P. Srihari, Tetrahedron Lett. 2009, 50, 2470-2473; c) Z.-X. Li, X.-P. Liu, Z. Qiu, D.-J. Xu, J. Chem. Res. 2011, 35, 35-36; d) O. Attanasi, P. Filippone, A. Mei, Synth. Commun. 1983, 13, 1203-1208; e) Shanthan Rao, R. V. Venkatratnam, Tetrahedron Lett. 1991,
32, 5821-5822; f) W. Bao, Y. Zhang, J. Wang, Synth. Commun. 1996, 26, 3025-3028.

[9] a) A. Lee, A. Michrowska, S. Sulzer-Mosse, B. List, Angew. Chem. 2011, 123, 1745-1748; Angew. Chem. Int. Ed. 2011, 50, 1707-1710; b) A. Rahmati, K. Vakili, Amino Acids 2010, 39, 911-916.

[10] a) K. Yamashita, T. Anaka, M. Hayashi, Tetrahedron 2005, 61, 7981-7985; b) D. Fildes, V. Caignaert, D. Villemin, P.-A. Jaffres, Green Chem. 2001, 3, 52-56.

[11] a) D. koszelewski, D. Paprocki, A. Madej, F. Borys, A. Brodzka, R. Ostaszewski, Eur. J. Org. Chem. 2017, 4572-4579; b) X. Garrabou, B. I. M. Wicky, D. Hilvert, J. Am. Chem. Soc. 2016, 138, 6972-6974.

[12] Y. Ogiwra, K. Takahashi, T. Kitazawa, N. Sakai, J. Org. Chem. 2015, 80, 3101-3110.

[13] a) R. C. M. Alves Sobrinho, P. M. de Oliveira, C. R. Montes D'Oca, D. Russowsky, M. G. Montes D'Oca, RCS Adv. 2017, 7, 3214-3221; b) H. Xu, L. Pan, X. Fang, B. Liu, W. Zhang, M. Lu, Y. Xu, T. Ding, H. Chang, Tetrahedron Lett. 2017, 58, 2360-2365; c) X. Hu, C. Ngwa, Q. Zheng, Curr. Org. Synth. 2016, 13, 101-110; d) X. M. Hu, Y. Zhao, Y. F. Gao, Y. B. Xiao, B. X. Zhang, Adv. Mater. Res. 2012, 554-556, 557-561.

[14] As further confirmation it was verified the activity of tetrabutylammonium acetate as catalyst in $10 \%$ amount that resulted operative after $1.5 \mathrm{~h}$ producing $91 \%$ yield.

Submitted: January 30, 2018

Revised: April 13, 2018

Accepted: April 18, 2018 